\title{
Amyotrophic Lateral Sclerosis
}

\author{
Aymeé Hernández* \\ Clinical Neurophysiology Department, Cuban Neuroscience Center, Cuba
}

Submission: February 22, 2017; Published: April 24, 2017

*Corresponding author: Aymeé Hernández, Clinical Neurophysiology Department, Cuban Neuroscience Center, Havana, Cuba, Email: barbara@cneuro.edu.cu

\section{Abstract}

Amyotrophic Lateral Sclerosis (ALS) is a neurodegenerative disorder of unknown cause. More of 400.000 persons are affected by ALS at world level. It is characterized by diffuse involvement of cortical, bulbar and spinal motor neurons. Physiopathology is very complex, there are a lot of changes into the neurons and glia that cause apoptosis and cellular degeneration. The diagnostic of this disorder is based in demonstrating of abnormalities of upper and lower motor neurons. It is based in neurophysiological studies and clinical signs, it is supported by Scorial criteria. New images methods could diagnosis and prognosis evolution of ALS patients and this methods show some important structural and functional abnormalities in nervous structures.

Keywords: Amyotrophic lateral sclerosis (ALS); Magnetic resonance image; Tensor of diffusion

\section{Introduction}

Amyotrophic Lateral Sclerosis (ALS) is a neurodegenerative disease of the voluntary way.

Upper and Lower motor neuron could degenerate. It the 3th more frequent neurodegenerative disease, overcome by Alzheimer and Parkinson Diseases. Some famous people like: Lu Gehrig, Jason Becker and Stephen Hawking have been affected by ALS [1].

\section{Epidemiology}

A. World Incidence: 2 × 100000 inhabitants.

B. World Prevalence: 5 - 8.5 x 100000 inhabitants.

C. Number of persons affected to world level: 400.000

D. Death in a year to world level: 100.000

E. Relation Man/Women: 2:1

F. Age of presentation: 40-60 years.

G. Survival: 3-5 years, 10 percent of the cases survival 10 or more years $[2,3]$.

\section{Forms of presentation}

A. Familiar form (10\% of cases).

B. Sporadic form (90\% of cases) [2-4].

\section{Physiopathology}

In ALS a multifactorial mechanism is proposed. Some factors are being in relation with ALS, some of them are: contact with heavy metals, organic solvents, organophosphorus substances, organochlorine substances, Selenium, Calcium, Magnesium, Manganese, Mercury, Lead, Cupper, Aluminum, Chrome, Tobaccoand Alcohol habits, Electric and Ellectro-magnetic fields. There are a lot of changes at cellular and molecular levels in neurons and glias. Superoxide Dismutase 1 enzyme (SOD1) dysfunction is the most general mechanism in ALS, it cause high levels of free radicals into de cell, destabilization of some important proteins and transporters, high levels of glutamate neurotransmitter outside the cell, glutamate mediated excitotoxicity, abnormalities of axonal transport, abnormalities of endoplasmic reticulum and mitochondria, abnormal proteins accumulation into the cells (Cytoplasmic Inclusions) . All of this changes could provoke apoptosis and neural degeneration $[5,6]$.

\section{Diagnosis}

Symptoms and signs include: muscular weakness, spasticity, hyper reflexia, clonus and Babinski sign, fasciculation, hypotonia and muscular atrophy. Diagnosis is based in Scorial criteria, it is support by clinical and neurophysiological examination and image techniques. Differential diagnosis of ALS is obligated with cervical spondylotic myelopathy, medullar tumor, syringomyelia. There is no an effective treatment for ALS [7-10].

\section{New diagnosis techniques}

Now days some magnetic resonance image techniques have been applied to diagnosis and prognosis the evolution of ALS patients, and some parameters have demonstrate abnormalities in non-motor structures: 
A. Voxel based morphometry: It has showed diminish of gray matter in pre-central and frontal medium gyrus; diminish of white matter of upper frontal region, pre-central and lower temporal gyrus.

B. Diffusion Technique: It has showed:

1. Increase of Mean Coefficient of Diffusion (MCD) in precentral, post-central, lower frontal, angular, supramarginal and medium temporal gyrus, insula, putamen nucleus, orbito-frontal white matter, internal capsule, corpus callosum and cerebellum.

2. Diminish of Fractional Anisotropy (AF) in white matter in pre-central, lower frontal and pre-motor areas.

3. Cortical Thickness: It is diminished in primary motor cortex, lower parietal region and lower temporal gyrus.

4. Volumetric Analysis: Diminish of volume of hippocampus, basal ganglia and limbic structures. Increase of volume of lateral ventricles [11-15].

\section{Conclusion}

Some markers of ALS need to be founded, new image techniques could be good candidates to show structural and functional abnormalities of nervous system structures in ALS patients.

\section{References}

1. Kiernan MC, Vucic S, Cheah BC, Turner MR, Eisen A, et al. (2011). Amyotrophic lateral sclerosis. Lancet 377(9769): 942-955.

2. Dugdale DC, Hoch DB, Zieve D (2010) Amyotrophic lateral sclerosis. A.D.A.M. Medical Encyclopedia.

3. Robert H Brown (2005) Principles of neurology. In: Rooper AH, et al. (Eds.), McGraw-Hill, New York, USA, pp. 120-158.
4. García Gálvez P, Cambón RS, Higes P, Sánchez Migallón MJ, Yustaizquierdo A (2011) Enfermedad de la motoneurona. Medicine 10(77): 5200-5208.

5. Ruiz Rodríguez AL, Clavijo D, Ramón O, Ruiz M, García A, et al. (2006) Bases biológicas y patobiológicas humanas de la esclerosis lateral Amiotrófica. Universitas Médica 47(1): 35-54.

6. Ferraiuolo L, Kirby J, Grierson AJ, Sendtner M, Shaw PJ (2011) Molecular pathways of motor neuron injury in amyotrophic lateral sclerosis. Nat Rev Neurol 7(11): 616-630.

7. Brooks BR (1994) El Escorial World Federation of Neurology criteria for the diagnosis of amyotrophic lateral sclerosis. J NeurolSci 124(Suppl1): 96- 107.

8. Bucheli M, Campos M, Bermudes D, Chuquimarca JP, Sambache K, et al. (2012) Esclerosis Lateral Amiotrófica: Criterios de El Escorial y la Electromiografía en su Temprano Diagnóstico. Revista Ecuatoriana de Neurología 15(3): 1-12.

9. Hernández A (2015) Amyotrophic Lateral Sclerosis can Mimic Orthopedic Disease - Cases Report. OAJNN 1(1): 1-9.

10. Hernández A (2016) ALS Diagnostic in the Electrodiagnostic Department of an Orthopedic Hospital during 2014-2015. Clinical and Electrophysiological Characteristic. OAJNN 1(2): 1-8.

11. Kollewe K, Korner S, Dengler R, Petri S, Mohammadi B (2012) Magnetic Resonance Imaging in Amyotrophic Lateral Sclerosis. Neurology Research International 2012: 1-9.

12. Agosta F, Chio A, Cosottini M, De Stefano N, Falini A, et al. (2010) The Present and the Future of Neuroimaging in Amyotrophic Lateral Sclerosis. AJNR Am J Neuroradiol 31(10): 1769 -1777.

13. Turner MR, Verstraete E (2015) What Does Imaging Reveal About the Pathology of Amyotrophic Lateral Sclerosis? CurrNeurolNeurosci Rep 15(7): 45 .

14. Foerster BR, Carlos RC, Dwamena BA, Callaghan BC, Petrou M (2014) Multimodal MRI as a diagnostic biomarker for amyotrophic lateral sclerosis. Annals of Clinical and Translational Neurology 1(2): 107114.

15. Douaud GI, Filippini N, Knight S, Talbot K, Turne MR (2011) Integration of structural and functional magnetic resonance imaging in amyotrophic lateral sclerosis. Brain 134(Pt 12): 3470-3479.

\section{Your next submission with Juniper Publishers} will reach you the below assets

- Quality Editorial service

- Swift Peer Review

- Reprints availability

- E-prints Service

- Manuscript Podcast for convenient understanding

- Global attainment for your research

- Manuscript accessibility in different formats

( Pdf, E-pub, Full Text, Audio)

- Unceasing customer service

Track the below URL for one-step submission

https://juniperpublishers.com/online-submission.php 